\title{
Perencanaan Sistem Pengelolaan Sampah Di PT PLN (Persero) Unit Pendidikan Dan Pelatihan
}

\author{
Robby Fiqry Maulana ${ }^{\text {; Netti Herlina }}{ }^{2}$; Lies Setyowati ${ }^{3}$; Randy Zulkarnain ${ }^{4}$ \\ ${ }^{1,3}$ Dosen Program Studi Teknik Lingkungan, Universitas Sumatera Utara (USU) \\ ${ }^{2}$ Mahasiswa Program Studi Teknik Lingkungan, Fakultas Teknik, Universitas Sumatera Utara (USU) \\ ${ }^{4}$ Instruktur UPDL Tuntungan, PLN Corporate University. \\ robbyfiqqry@gmail.com \\ ${ }^{2}$ netti@usu.ac.id \\ ${ }^{3}$ liessetyowati66@gmail.com \\ ${ }^{4}$ randy.zulkarnain@gmail.com
}

\begin{abstract}
The source of waste produced by PT PLN (Persero) UPDL Tuntungan comes from offices and classrooms, mess and dormitories, parks and roads as well as dining rooms. We need a good waste management system planning for optimisation existing waste treatment. The research objective is to calculate the generation and composition, plan operational techniques and waste management schemes. The method of measuring the generation and composition of waste uses SNI 19-3964-1994. The results of the study showed that the solid waste generation based on the maximum capacity produced was $210.10 \mathrm{~kg} /$ day or 1,752.23 l/day with the composition of the solid waste produced as a whole of food remaining $11.20 \%$, wood and plant waste $65.07 \%$, fabric/textile $1.59 \%$, rubber $1.26 \%$, plastic $10.80 \%$, metal $0.75 \%$, glass, $1.14 \%$, paper $5.34 \%$, tissue $1.29 \%$, and styrofoam 1 , $56 \%$. Garbage operational techniques that will be planned starting from storage using a $20 \mathrm{~L}$ bin will be divided into 5 types, namely organic, plastic, paper, etc. and hazardous and toxic materials, and placed 1 container of $120 \mathrm{~L}$ size garbage for trash from the dining room. Collection and transfer using 660L depot transfer. Transporting garbage using a $1 \mathrm{~m}^{3}$ garbage motor to the TPS for further composting and sorting. For garbage that still has a sale value, it is sold to pelapak and the residual waste is taken to the landfill.
\end{abstract}

Keywords: composition, management, waste, generation, education

\begin{abstract}
ABSTRAK
Sumber sampah yang dihasilkan oleh PT PLN (Persero) Unit Pelaksana Pendidikan dan Pelatihan (UPDL) Tuntungan berasal dari kantor dan kelas, mess dan asrama, taman dan jalan serta ruang makan. Belum optimalnya pengelolaan sampah eksisting, maka diperlukan suatu perencanaan sistem pengelolaan sampah yang baik. Tujuan penelitian adalah menghitung timbulan dan komposisi, merencanakan teknik operasional dan skema pengelolaan sampah. Metode pengukuran timbulan dan komposisi sampah menggunakan SNI 19-3964-1994. Hasil studi menunjukan bahwa timbulan sampah berdasarkan daya tampung maksimum yang dihasilkan adalah 210,10 kg/hari atau $1.752,23$ l/hari dengan komposisi sampah yang dihasilkan secara keseluruhan adalah sisa makanan $11,20 \%$, kayu dan sampah tanaman 65,07\%, kain/tekstil 1,59\%, karet 1,26\%, plastik 10,80\%, logam $0,75 \%$, kacalgelas $1,14 \%$, kertas 5,34\%, tisu 1,29\%, dan styrofoam 1,56\%. Teknik operasional sampah yang akan direncanakan dimulai dari pewadahan menggunakan bin 20 L akan dibedakan menjadi 5 jenis yaitu organik, plastik, kertas, lain-lain dan bahan berbahaya dan beracun (B3), serta ditempatkan 1 kontainer sampah ukuran 120 L untuk sampah dari ruang makan. Pengumpulan dan pemindahan menggunakan transfer depo 660 L. Pengangkutan sampah menggunakan motor sampah kapasitas $1 \mathrm{~m}^{3}$ menuju TPS untuk selanjutnya dilakukan pengomposan dan pemilahan. Untuk sampah yang masih memiliki nilai jual, dijual ke pelapak dan sampah residu dibawa ke TPA.
\end{abstract}

Kata kunci: Komposisi, Pengelolaan, Sampah, Timbulan, UPDL 


\section{KILAT}

Vol. 9, No. 1, April 2020, P-ISSN 2089-1245, E-ISSN 2655-4925

DOI: https://doi.org/10.33322/kilat.v9i1.747

\section{PENDAHULUAN}

PT PLN (Persero) Unit Pelaksana Pendidikan dan Pelatihan (UPDL) Tuntungan memiliki luas wilayah sebesar $59.000 \mathrm{~m}^{2}$ yang terdiri dari 9 Kantor, 17 Kelas , dan 96 Kamar. Pada tahun 2017, PT PLN (Persero) UPDL Tuntungan memiliki jumlah karyawan sebanyak 25 karyawan tetap dan 47 karyawan outsorcing serta dapat menampung peserta sebanyak 300 orang setiap harinya. Sampah yang dihasilkan dari aktivitas di UPDL Tuntungan dikumpulkan dalam tempat sampah yang disediakan di masing-masing ruang, kemudian sampah tersebut dimasukkan kedalam tempat sampah yang terpilah dalam sampah 3 jenis (organik, anorganik, dan lain-lain). Kemudian sampah dibawa dalam kondisi bercampur hingga menuju lapangan terbuka di lahan belakang UPDL Tuntungan setiap 2 hari sekali. Secara eksisting telah memiliki Tempat Pengolahan Sampah Sementara (TPS), namun belum dimaksimalkan. Dengan kondisi tersebut, maka perlu dilakukan perencanaan sistem pengelolaan sampah sehingga PT PLN (Persero) UPDL Tuntungan dapat mengelola sampahnya dengan baik sesuai dengan Undang-undang No.18 tahun 2008.

\subsection{Tujuan}

Beberapa penelitian serupa dengan lokasi wisma dan kampus, memiliki metode yang sama yaitu dengan mengidentifikasi komposisi sampah langsung dilapangan untuk kemudian mendesain sistem teknis operasional dan rekomendasi pengolahan sampah organik dan anorganik. Namun tidak semua penelitian yang melakukan penghitungan Rencana Anggaran Biaya untuk melaksanakan desain rekomendasi tersebut. ([1]; [2]; [3]; [4]; [5]). Adapun tujuan dari penelitian ini adalah sebagai berikut:

1. Menghitung timbulan dan komposisi sampah yang dihasilkan di PT PLN (Persero) UPDL Tuntungan

2. Merencanakan teknik operasional pengelolaan sampah yang dapat diusulkan berdasarkan daya tampung maksimum di PT PLN (Persero) UPDL Tuntungan

3. Merencanakan pengolahan sampah dan merancang skema pengelolaan sampah.

\section{METODE PENELITIAN}

\subsection{Pendataan Timbulan dan Komposisi Sampah}

Pendataan timbulan dan komposisi sampah yang dilakukan mengacu pada standar pengukuran sampah SNI 19-3964-1994 selama 8 hari [6].

\subsection{Perencanaan Teknik Operasional Pengelolaan Sampah}

Perencanaan teknik operasional pengelolaan persampahan mengacu pada SNI 19-2454-2002 yang dimulai dari pewadahan, pengumpulan dan pemindahan, pengangkutan, pengolahan dan pemrosesan akhir [7].

\subsection{Asumsi Perencaanaan Berdasarkan Jumlah Peserta PT PLN (Persero) UPDL Tuntungan}

Berdasarkan data dari PT PT PLN (Persero) UPDL Tuntungan, jumlah peserta diklat selama 8 tahun terakhir tidak mengalami kenaikan signifikan yaitu \pm 301 orang perharinya. Berdasarkan jumlah daya tampung, PT PT PLN (Persero) UPDL Tuntungan dapat menampung siswa sebanyak 480 orang perhari. Dengan pertimbangan tersebut maka perencanaan yang diambil sebanyak 400 orang perhari, dengan jumlah karyawan sebanyak 72 orang. 


\section{HASIL DAN PEMBAHASAN}

\subsection{Timbulan dan Komposisi Sampah}

Pengambilan sampel sampah di lapangan dilakukan selama 8 hari kerja berturut-turut yang tercatat dari mulai tanggal 6, 7, 10, 12, 13, 14, 17 dan 18 September 2018. Dalam menentukan besaran timbulan sampah berdasarkan Berat (kg) dan Volume (1) di PT PLN (Persero) UPDL Tuntungan, sampel akan dibagi menjadi kantor dan kelas, mess dan asrama, sampah jalan serta sampah ruang makan.

\section{a. Timbulan Sampah Kantor Dan Kelas}

Pengukuran tidak menggunakan metode sampling karena jumlah penghasil sampah yang tidak tetap pada suatu ruang, sehingga dilakukan pengukuran keseluruhan sampah dengan mengukur timbulan sampah kantor dan kelas yang dihasilkan dalam satu hari. Di dapat rata-rata berat asal timbulan sampah kantor dan kelas di PT PLN (Persero) UPDL Tuntungan yaitu $0,21 \mathrm{~kg} / \mathrm{org} / \mathrm{hari}$, sedangkan volume asal yaitu 1,95 1/org/hari dengan ratarata perhari 83 orang.

Berdasarkan SNI 19-3964-1994, besaran timbulan yang dihasilkan dari kantor ataupun kelas adalah $0,025-0,1 \mathrm{~kg} / \mathrm{org} / \mathrm{hari}$ atau $0,5-0,75 \mathrm{l} / \mathrm{org} / \mathrm{hari}$ [6]. Sementara kantor dan ruang kuliah Fakultas Peternakan dan Pertanian Universitas Dipenogoro, besaran timbulan yang dihasilkan adalah $0,016 \mathrm{~kg} / \mathrm{org} / \mathrm{hari}$ atau $0,282 \mathrm{l} / \mathrm{org} / \mathrm{hari}$ [5]. Timbulan sampah di Fakultas Psikologi dan Fakultas Kesehatan Masyarakat Universitas adalah 0,039 kg/org/hari atau 0,517 1/org/hari kemudian Fakultas Kesahatan Masyarakat Universitas Dipenogoro berdasarkan adalah 0,0024 kg/org/hari atau 0,240 1/org/hari [4].

Dengan demikian, timbulan sampah kantor dan kelas di PT PLN (Persero) UPDL Tuntungan lebih besar daripada nilai yang ditetapkan SNI 19-3964-1994 dan juga lebih besar dari Fakultas Peternakan dan Pertanian, Fakultas Psikologi, dan Fakultas Kesahatan Masyarakat Universitas Dipenogoro.

\section{b. Timbulan Sampah Mess dan Asrama}

Dalam menentukan besaran timbulan sampah di mess dan asrama dilakukan dengan metode sampling sesuai SNI 19-3964-1994, jumlah sampel sebesar 10\% dari jumlah seluruh unit [6]. Total unit mess dan asrama sebanyak 54 unit, maka dilakukan pengukuran sebanyak 6 titik sampel, sehingga di dapat rata-rata timbulan sampah mess dan asrama di PT PLN (Persero) UPDL Tuntungan berdasarkan berat asal yaitu $0,15 \mathrm{~kg} / \mathrm{org} / \mathrm{hari}$, sedangkan berdasarkan volume asal yaitu 1,95 1/org/hari.

Berdasarkan SNI 19-3964-1994, besaran timbulan sampah yang dihasilkan dari rumah non permanen adalah 0,250 - 0,300 kg/org/hari atau 1,75 - 2,00 1/org/hari [6]. Sementara, besaran timbulan di Rusunawa Universitas Dipenogoro adalah $0,11 \mathrm{~kg} / \mathrm{org} / \mathrm{hari}$ atau 0,85 1/org/hari [3]. Sementara timbulan dan komposisi sampah di kawasan perkantoran dan wisma Werdhapura Village Center, Kota Denpasar, Provinsi Bali pada bulan Juni timbulan yang dihasilkan sebesar $0,253 \mathrm{~kg} / \mathrm{org} /$ hari atau 5,323 1/org/hari, pada bulan Juli sebesar 0,344 kg/org/hari atau 7,040 1/org/hari dan pada bulan Agustus sebesar 0,17 kg/org/hari atau 2,485 1/org/ hari [1].

Dengan Demikian, dapat diketahui timbulan sampah timbulan sampah mess dan asrama di PT PLN (Persero) UPDL Tuntungan lebih kecil daripada nilai yang ditetapkan SNI 193964-1994 dan Timbulan Dan Komposisi Sampah Di Kawasan Perkantoran dan Wisma Wisma (Studi Kasus: Werdhapura Village Center, Kota Denpasar, Provinsi Bali), namun lebih besar dibandingkan dengan besaran timbulan di Rusunawa Universitas Dipenogoro. 


\section{KILAT}

Vol. 9, No. 1, April 2020, P-ISSN 2089-1245, E-ISSN 2655-4925

DOI: https://doi.org/10.33322/kilat.v9i1.747

\section{c. Timbulan Sampah Jalan dan Taman}

Luas ruang terbuka sebesar $43.488 \mathrm{~m} 2$, dengan rincian ruang terbuka hijau sebesar 29.120 $\mathrm{m} 2$ dan ruang terbuka non hijau sebesar $14.368 \mathrm{~m} 2$. Metode pengukuran berat dan volume sampah berdasarkan jumlah yang dihasilkan jalan dan taman dalam sehari. Rata-rata timbulan jalan dan taman di PT PLN (Persero) UPDL Tuntungan berdasarkan berat asal yaitu $0,00118 \mathrm{~kg} / \mathrm{m} 2 / \mathrm{hari}$, dan volume asal yaitu $0,00693 \mathrm{l} / \mathrm{m} 2 / \mathrm{hari}$.

Berdasarkan SNI 19-3964-1994, timbulan sampah yang dihasilkan dari jalan lokal adalah 0,005 kg/m2/hari atau 0,025 1/m2/hari [6]. Sementara di Fakultas Peternakan dan Pertanian Universitas Dipenogoro, besaran timbulan sampah kebun-jalan adalah 0,0024 kg/m2/hari atau $0,07658 \mathrm{l} / \mathrm{m} 2 /$ hari [5].

Dengan demikian, dapat disimpulkan jumlah sampah jalan dan taman di PT PLN (Persero) Udiklat Tuntungan lebih kecil dibandingkan dengan SNI 19-3964-1994 dan juga Fakultas Peternakan dan Pertanian Universitas Dipenogoro.

\section{d. Timbulan Sampah Ruang Makan}

Metode pengukuran berat dan volume sampah di ruang makan berdasarkan jumlah yang dihasilkan dalam satu hari selama 8 hari bertutut-turut. Perhitungan rata-rata timbulan sampah ruang makan yaitu $0,06 \mathrm{~kg} / \mathrm{org} / \mathrm{hari}$, dan volume asal yaitu 0,16 1/org/hari dengan jumlah rata-rata 83 orang perhari.

e. Komposisi Sampah Secara Keseluruhan

Komposisi sampah yang dihasilkan secara keseluruhan adalah sisa makanan 11,20\%, kayu dan sampah tanaman $65,07 \%$, kain/tekstil 1,59\%, karet 1,26\%, plastik 10,80\%, logam $0,75 \%$, kaca/gelas $1,14 \%$, kertas $5,34 \%$, tisu $1,29 \%$, dan styrofoam $1,56 \%$.

\subsection{Perencanaan Sistem Teknis Operasional Pengelolaan Sampah Berdasarkan Daya}

\section{Tampung Maksimum di PT PLN (Persero) UPDL Tuntungan}

Teknik Operasional Pengelolaan PT PLN (Persero) UPDL Tuntungan didesain dengan memperhitungkan daya tampung maksimum [7] siswa \pm 400 orang/hari ditambah jumlah karyawan 25 orang pegawai tetap dan 47 outsouching, maka didapat berat timbulan sampah $210,10 \mathrm{~kg} / \mathrm{hari}$ dan total volume timbulan sampah 1752,23 1/hari, (1688,23 1/hari untuk kantor, kelas, mess, asrama, taman \& jalan, 64 1/hari untuk ruang makan).

Untuk memudahkan rencana teknik operasional pengelolaan sampah, PT PLN (Persero) UPDL Tuntungan akan di bagi menjadi 3 area ( Area A, Area B dan Area C).

\section{a. Pewadahan}

Pewadahan yang direncanakan terpilah menjadi 5 jenis sampah [8], yaitu warna Hijau untuk Sampah Organik (sisa makanan serta kayu dan sampah taman), Biru untuk sampah Plastik, Kuning untuk Sampah Kertas dan Karton, Abu-abu untuk Sampah Lain-lain (kain, karet, logam, kaca, tisu, styrofoam) serta Merah untuk Sampah Bahan Berbahaya dan Beracun (B3). 


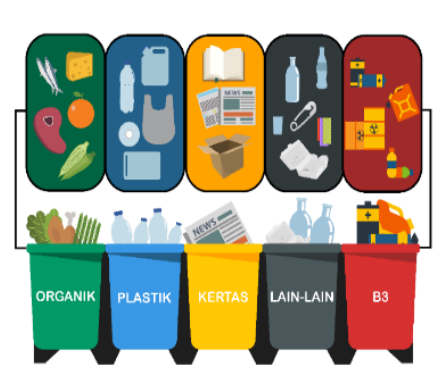

(a)

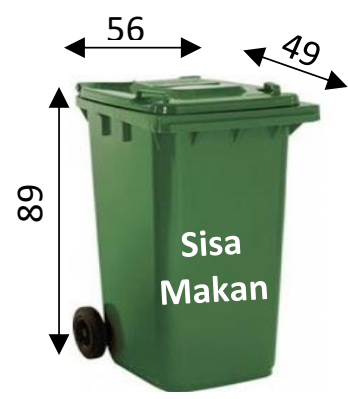

(b)

Gambar 1. (a) Pewadahan Komunal 5 Jenis (b) Pewadahan Khusus Ruang Makan

Berdasarkan perhitungan volume timbulan sampah maksimal diatas, maka direncanakan sebanyak 21 unit Bin kapasitas 20 liter yang tersebar pada selurh area berikut:

Area A : A1,( A2, A3, A4 : Kelas Jamin Ginting Lt.1, Lt.2, Lt.3), A5, A6, A7, A8, A9, dan A10

Area B : B1, B2, B3, B4, dan B5 (Asrama Sibayak : Lt.1, Lt.2), B6, dan B7

Area C : D1, D2, D3 : Asrama Sinabung Lt.1, Lt. 2,Lt.3) dan $\mathrm{D} 4$

sedangkan khusus untuk ruang makan akan diwadahi tersendiri menggunakan $120 \mathrm{~L}$, karena komposisi hanya berupa sisa makanan.

\section{b. Pengumpulan dan Pemindahan}

Pengumpulan direncanakan secara manual dengan mengambil sampah dari setiap bin menuju container pengumpul $660 \mathrm{~L}$ yang akan didesain dengan menggunakan sekat pembatas sehingga terbagi menjadi 5 jenis sampah.

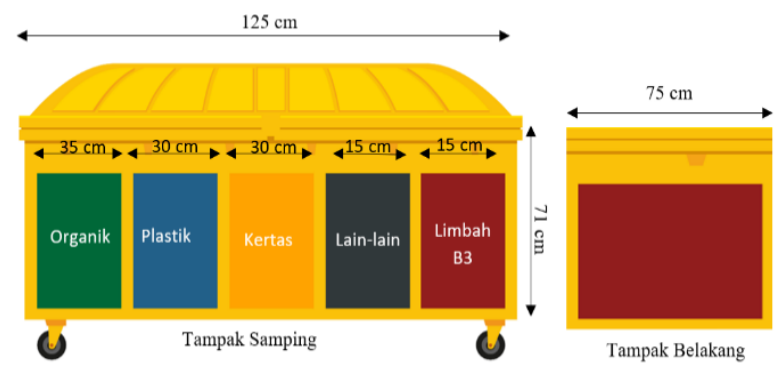

Gambar 2. Pengumpulan dan Pemindahan Menggunakan Kontainer 660L

Kontainer pengumpul yang diperlukan ialah 3 unit kontainer, dimana kontainer pengumpul I untuk area A, kontainer pengumpul II untuk area B, dan kontainer pengumpul III untuk area C. Pengumpulan dan pemindahan sampah yang yang direncanakan ialah:

Kontainer A : A1 - A2 - A3 - A4 - A5 - A6 - A7 - A8 - A9 - A10 - Tempat - Pengangkutan Kontainer B : B1 - B2 - B3 - B4 - B5 - B6 - B7 - Tempat Pengangkutan Kontainer C : D1 - D2 - D3 - D4 - Tempat Pengangkutan 


\section{KILAT}

Vol. 9, No. 1, April 2020, P-ISSN 2089-1245, E-ISSN 2655-4925

DOI: https://doi.org/10.33322/kilat.v9i1.747

\section{c. Pengangkutan}

Pengangkutan direncanakan menggunakan motor sampah $1 \mathrm{~m}^{3}$. Setiap hari, 1 unit motor pengangkut melakukan 2 ritasi. Untuk menuju TPS eksisting, motor sampah didesain dengan 5 jenis bak sampah yaitu bak sampah organik, plastik, kertas, lain-lain, dan limbah B3 yang masing-masing dimensinya disesuaikan dengan komposisi penghasil sampah.

Pengangkutan yang direncanakan ialah:

Pengangkut Ritasi I : Kontainer A - DD1 - TPS eksisiting

Pengangkut Ritasi II : Kontainer B - Kontainer C - TPS eksisting

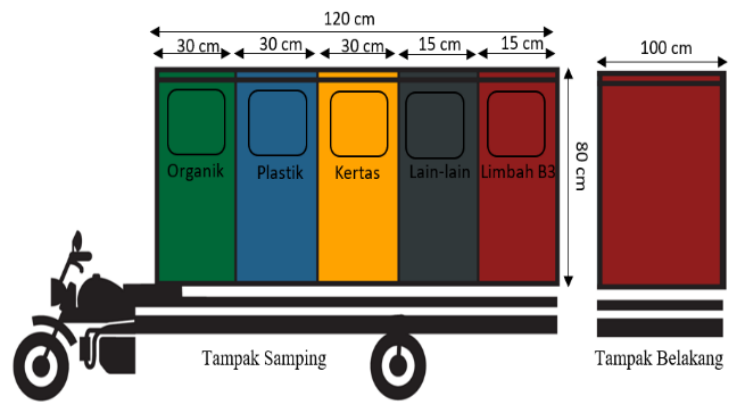

Gambar 3. Pengangkutan Menggunakan Motor Sampah $1 \mathrm{~m}^{3}$

\section{d. Pengolahan Sampah}

Pengolahan sampah yang direncanakan di TPS PT PLN (Persero) UPDL Tuntungan yaitu sampah organik menjadi kompos, sampah plastik dan kertas akan dijual kepada pelaku daur ulang, sampah lain-lain akan dilakukan pemilahan kemudian yang memiliki nilai ekonomis akan dijual, sisanya/residu dibuang menuju TPA.

\subsection{Skema Eksisting Pengelolaan Sampah di PT PLN (Persero) UPDL Tuntungan}

Pengelolaan sampah eksisting PT PLN (Persero) UPDL Tuntungan yaitu dimulai dari sumber sampah kemudian pengumpulan sampah dan pengangkutan sampah menuju tempat pembuangan sampah lahan terbuka. Sampah tidak dilakukan pengolahan, hanya sisa makanan yang akan diberikan untuk pakan ternak. 


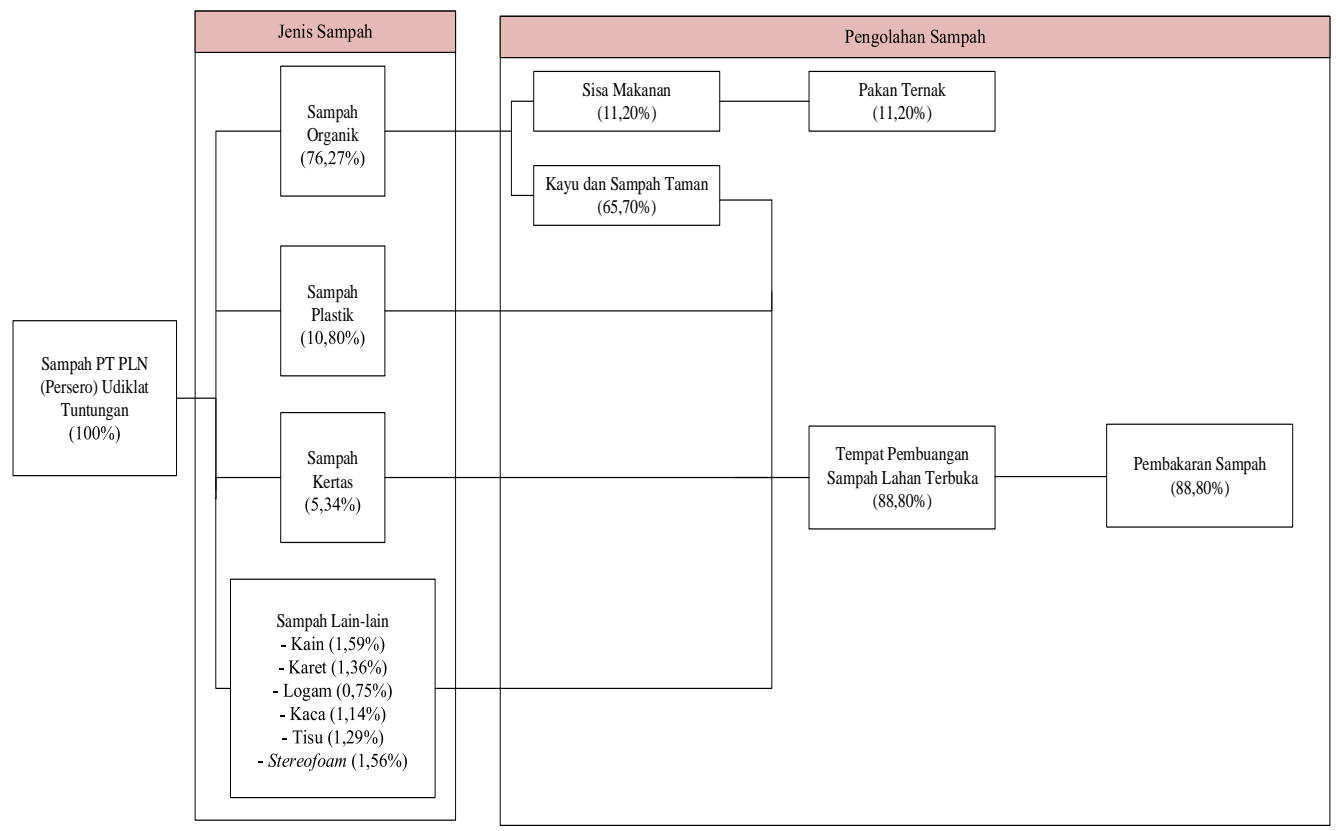

Gambar 4. Skema Eksisisting Pengelolaan Sampah di PT PLN (Persero) UPDL Tuntungan

\subsection{Skema Rencana Pengelolaan Sampah di PT PLN (Persero) UPDL Tuntungan}

Berikut adalah skema rencana pengelolaan sampah di PT PLN (Persero) UPDL Tuntungan, hingga bisa mengurangi sampah yang menuju TPA sebesar 76,53\%.

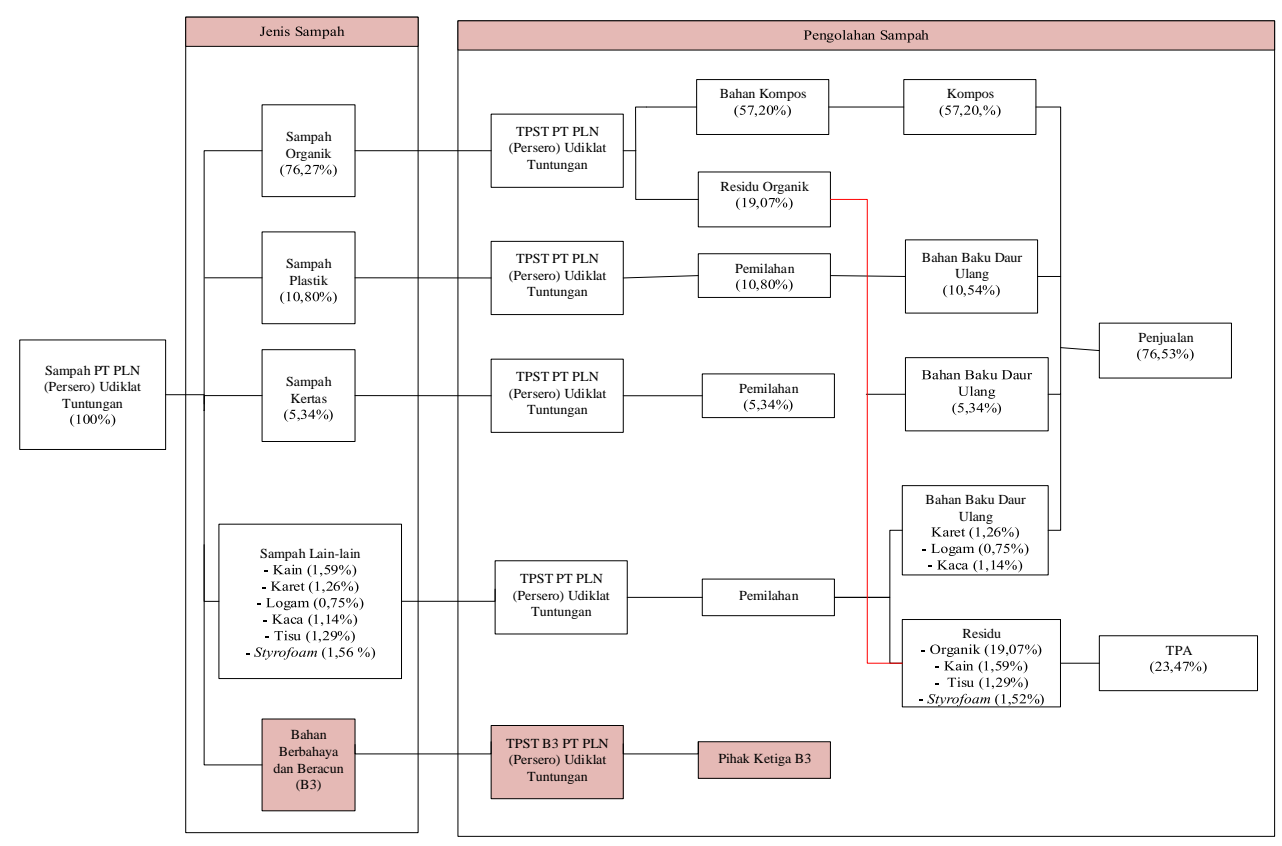

Gambar 5. Skema Rencana Pengelolaan Sampah di PT PLN (Persero) UPDL Tuntungan

Sejak November 2018, ada kebijakan dari manajemen UPDL Tuntungan untuk tidak lagi mennggunakan air minum dalam kemasan, sehingga jenis sampah plastik dapat berkurang menjadi $4,8 \%$. 


\section{KILAT}

Vol. 9, No. 1, April 2020, P-ISSN 2089-1245, E-ISSN 2655-4925

DOI: https://doi.org/10.33322/kilat.v9i1.747

Standar Operasional Prosedur perlu dibuat agar pengelolaan sampah yang di rencanakan di PT PLN (Persero) UPDL Tuntungan berjalan dengan baik. Standar operasional prosedur merupakan panduan untuk melakukan pengelolaan sampah yang direncanakan.

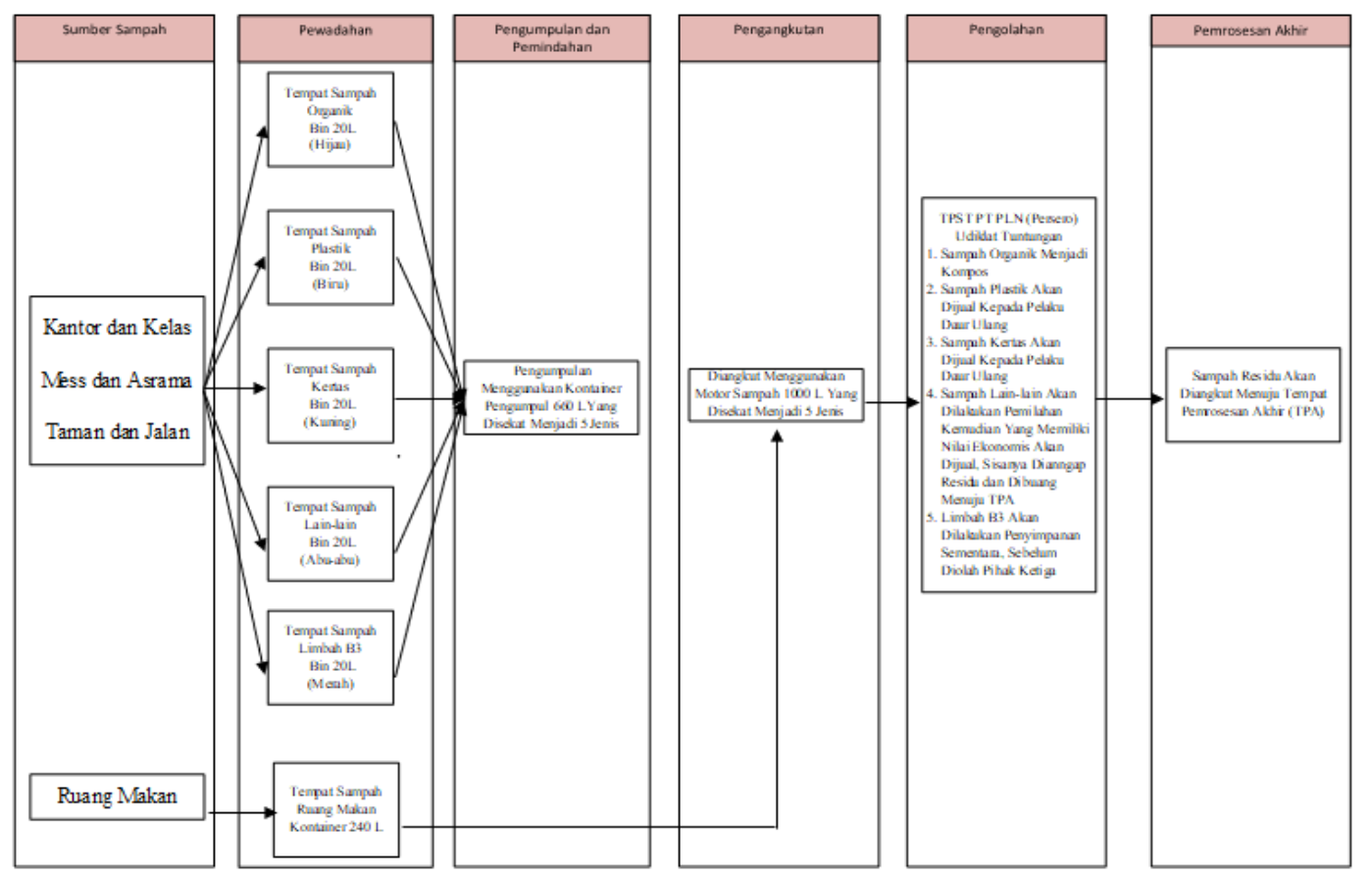

Gambar 6. Standar Operasional Prosedur Pengelolaan Sampah di PT PLN (Persero) UPDL Tuntungan

\section{Kesimpulan}

Adapun kesimpulan dalam merencanakan sistem pengelolaan sampah di PT PLN (Persero) UPDL Tuntungan adalah:

1. Timbulan sampah berdasarkan daya tampung maksimum sebesar $210,10 \mathrm{~kg} / \mathrm{hari}$, atau 1752,23 1/hari, dengan rincian jumlah timbulan sampah yang dihasilkan dari kelas dan kantor adalah $0,21 \mathrm{~kg} / \mathrm{org} / \mathrm{hari}$ atau 1,95 1/org/hari, mess dan asrama $0,15 \mathrm{~kg} / \mathrm{org} / \mathrm{hari}$ atau 1,96 1/org/hari jalan dan taman 51,28 kg/hari atau 301,35 1/hari dan ruang makan 0,09 $\mathrm{kg} / \mathrm{org} /$ hari atau 0,69 1/org/hari. komposisi sampah yang dihasilkan secara keseluruhan dalam adalah sisa makanan 11,20\%, kayu dan sampah tanaman 65,07\%, kain/tekstil 1,59\%, karet $1,26 \%$, plastik 10,80\%, logam $0,75 \%$, kaca/gelas $1,14 \%$, kertas $5,34 \%$, tisu $1,29 \%$, dan stereofoam $1,56 \%$.

2. Teknik Operasional Sampah yang akan direncanakan dimulai dari :

a. Pewadahan dengan menggunakan Bin $20 \mathrm{~L}$ dengan yang dibedakan menjadi 5 jenis pemilahan yaitu warna Hijau untuk Sampah Organik, Biru untuk Plastik, Kuning untuk Sampah Kertas dan Karton, Abu-abu untuk Sampah Lain-lain serta Merah untuk Sampah Bahan Berbahaya dan Beracun (B3) yang terpasang sebanyak 21 pasang Bin sampah, serta ditempatkan 1 kontainer sampah ukuran 120L untuk sampah yang dihasilkan dari ruang makan karena komposisi sampah hanya berupa sisa makanan.

b. Pengumpulan dan Pemindahan menggunkan transfer depo $660 \mathrm{~L}(125 \mathrm{~cm} \times 71 \mathrm{~cm} \times$ $74 \mathrm{~cm}$ ) yang disekat menjadi 5 jenis sampah yang terbagi menjadi 3 area setiap unit.

c. Pengangkutan Sampah menggunakan motor sampah kapasitas $1 \mathrm{~m} 3(120 \mathrm{~cm}$ x 100 cm x $80 \mathrm{~cm}$ ) yang disekat menjadi 5 jenis sampah diangkut menuju TPST PLN (Persero) UPDL Tuntungan sebaanyak 2 ritasi/hari. 
3. TPS eksisting PT PLN (Persero) UPDL Tuntungan dimaksimalkan untuk melakukan pengomposan dan pemilahan sampah plastik, kertas dan lain-lain serta residu. Selanjutnya residu akan dibuang ke TPA.

\section{DAFTAR PUSTAKA}

[1] M. W. Wardiha, P. S. Putri, L. M. Setyawati, and Muhajirin, "WISMA (Studi Kasus: Werdhapura Village Center, Kota Denpasar, Provinsi Bali)," 2013.

[2] S. Raharjo, T. Ihsan, and Y. Ruslinda, "Perencanaan Sistem Reduce, Reuse Dan Recycle Pengelolaan Sampah Di Kampus Universitas Andalas Limau Manis Padang," J. Dampak, vol. 11, no. 2, p. 79, Jul. 2014.

[3] K. Finasia Sakina Harsari, I. Bagus Priyambada, and B. Prasetyo Samadikun, "Studi Timbulan, Komposisi Dan Karakteristik Dalam Perencanaan Teknis Operasional Rusunawa Dan Lppu Universitas Diponegoro,” 2016.

[4] R. Fitria, B. P. Samadikun, and I. B. Priyambada, "Studi Timbulan, Komposisi Dan Karakteristik Dalam Perencanaan Pengelolaan Sampah Universitas Diponegoro Studi Kasus: Fakultas Psikologi Dan Fakultas Kesehatan Masyarakat," Semarang, 2016.

[5] K. C. Mita Sekar, B. Prasetyo Samadikun, and I. Bagus Priyambada, "Studi Timbulan, Komposisi Dan Karakteristik Dalam Perencanaan Pengelolaan Sampah Di Fakultas Peternakan Dan Pertanian Universitas Diponegoro," 2016.

[6] Badan Standarisasi Nasional, "Standar Nasional Indonesia 19-3964-1994 Tentang Metode Pengambilan Dan Pengukuran Contoh Timbulan Dan Komposisi Sampah Perkotaan," 1994.

[7] Badan Standardisasi Nasional, "Standar Nasional Indonesia 19-2454-2002 Tata cara teknik operasional pengelolaan sampah perkotaan,” 2002.

[8] "Peraturan Pemerintah Republik Indonesia Nomor 81 Tahun 2012 Tentang Pengelolaan Sampah Rumah Tangga Dan Sampah Sejenis Sampah Rumah Tangga,” 2012. 